\title{
Оценка влияния экономического спада и антироссийских санкций на регионы РФ 1
}

С.В. КАЗАНЦЕВ, доктор экономических наук, заместитель директора Института экономики и организации промышленного производства СО РАН, Новосибирск. E-mail: kzn-sv@yandex.ru

В статье дается оценка потенциальной опасности негативных воздействий на экономику Российской Федерации и ее регионов таких факторов, как неблагоприятная геополитическая ситуация, ухудшающаяся конъюнктура мировых товарных рынков, санкции в отношении России и экономический спад внутри страны. Показано, что под влиянием этих и других причин социально-экономическое развитие части российских регионов замедлилось, экономическое положение - ухудшилось. Согласно расчетам, сила влияния экономического спада в России, ухудшения конъюнктуры на мировых товарных рынках и введенных против Российской Федерации финансово-экономических санкций на изменение совокупности анализируемых показателей в российских регионах прямо пропорциональна зависимости хозяйствующих субъектов от иностранного капитала, внешних источников финансирования и внешнеторгового оборота. Выявлены субъекты Федерации, наиболее и наименее зависимые от этих факторов.

Ключевые слова: антироссийские санкции, экономические угрозы, субъекты Российской Федерации, экономический рост

\section{Последствия санкций}

\section{и ухудшения мировой конъюнктуры}

С 2014 г. ситуация на мировых товарных рынках ${ }^{2}$ ухудшается. Кроме того, с марта 2014 г. действует пакет санкций (финансово-экономических, научно-технологических, торговых и др.), введенных правительствами ряда стран в отношении России. А в результате сокращается объем внешней торговли Российской Федерации и уменьшается приток в страну иностранных инвестиций (рис. 1, 2), что влечет за собой ряд негативных последствий.

\footnotetext{
${ }^{1}$ Статья подготовлена по плану НИР ИЭОПП СО РАН в рамках приоритетного направления IX.87 (проект IX.87.1.3).

2 Понятие «товар» включает в себя и выносимые на рынок услуги.
} 
Млрд долл.

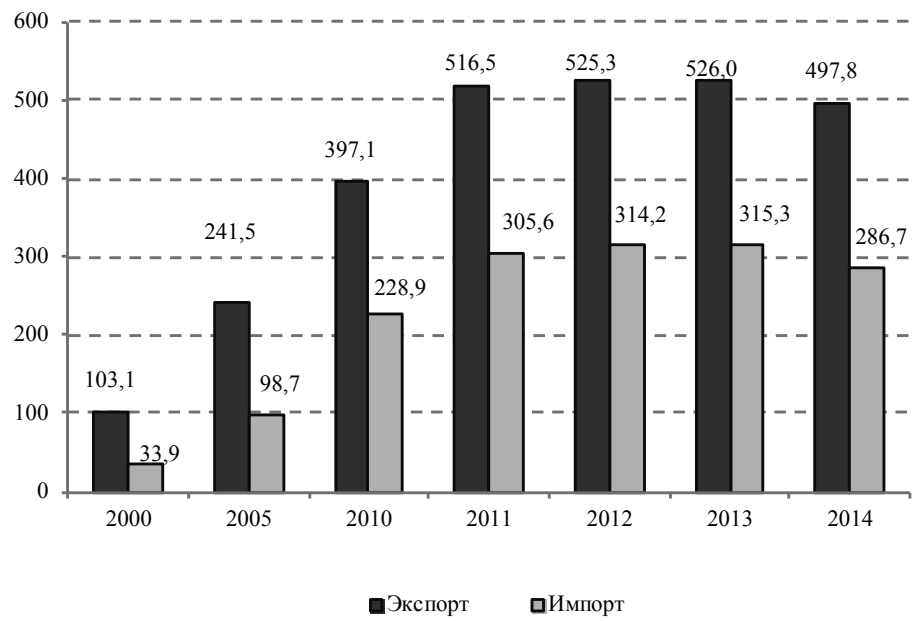

Источник рис. 1-4: составлены по данным стат. сб.: «Регионы России. Социально-экономические показатели» за 2010-2015 гг. [1].

Рис. 1. Динамика экспорта и импорта РФ в 2000-2014 гг., млрд долл. США

Млрд долл.

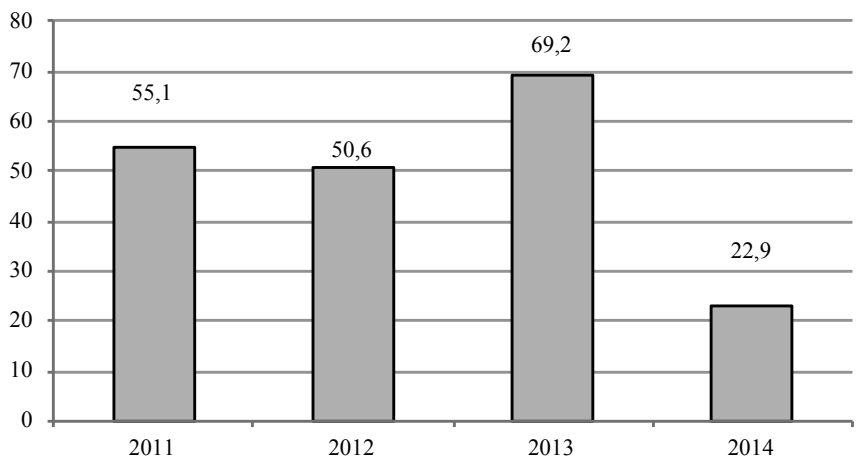

Рис. 2. Поступление прямых иностранных инвестиций в РФ в 2011-2014 гг. (сальдо операций платежного баланса РФ), млрд долл. США 
Во-первых, поскольку доля доходов от внешнеэкономической деятельности в доходах федерального бюджета в последние годы близка к $40 \%$, а в доходах консолидированного бюджета находится на уровне 18-22\%, сокращение экспорта российских товаров и услуг приводит к падению доходов федерального бюджета и экспортоориентированных хозяйствующих субъектов.

Во-вторых, свертывание объемов производства работающих на экспорт предприятий и их доходов вызывает сокращение занятости и, как следствие, меньший объем налоговых поступлений в бюджеты всех уровней. В доходах консолидированного бюджета РФ только налоги на прибыль и доходы физических лиц составляют около $20 \%$.

В-третьих, основными статьями, на которые приходится более $80 \%$ общего объема импорта РФ из стран дальнего зарубежья ${ }^{3}$, выступают машины, оборудование и транспортные средства; продукция химической промышленности; продовольственные товары и сельскохозяйственное сырье. Зависимость российского рынка от импортных продуктов существенна, в том числе по программному обеспечению и наукоемким изделиям. Поэтому сокращение объемов импорта (рис. 3), ограничения на экспорт в Россию технологий тормозят развитие ряда производств, что также чревато уменьшением занятости, доходов населения и федерального, региональных и местных бюджетов, а неудовлетворенный платежеспособный спрос стимулирует рост цен.

В-четвертых, вызванное антироссийскими санкциями ограничение возможностей получения отечественными хозяйствующими субъектами зарубежных кредитов ухудшило ситуацию на внутреннем финансовом рынке. Многие хозяйствующие субъекты не могут привлечь необходимые им финансовые ресурсы. Недоступность внешних источников финансирования при отсутствии их равноценной замены внутренними сдерживает развитие производства и технологического прогресса. Это ведет не только к описанным выше последствиям, но и к углублению технологического отставания от занимающих передовые рубежи науки и техники стран. Последнее к тому же затрудняет встраивание России в мировые цепочки производства продуктов.

\footnotetext{
${ }^{3}$ Страны дальнего зарубежья - все государства, кроме вышедшихиз состава СССР его бывших союзных республик.
} 


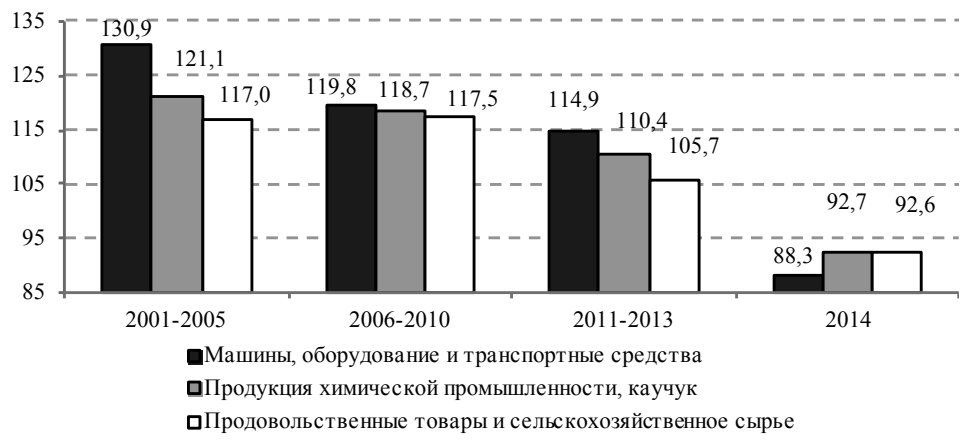

Рис. 3. Среднегодовые темпы роста импорта в РФ в 2000-2014 гг.,\%

В-пятых, антироссийские санкции блокируют проведение финансовых операций попавших в санкционные списки ${ }^{4}$ физических и юридических лиц (прежде всего, государственных компаний и предприятий с государственным участием) через иностранные банки, они не могут пользоваться услугами международной финансовой системы.

\section{Оценка потенциальной опасности}

Неблагоприятная геополитическая обстановка, сжатие мировых товарных рынков и действующие с марта 2014 г. расширяемые и «уточняемые» (по терминологии их авторов) антироссийские санкции ${ }^{5}$ ограничивают возможности социально-экономического и научно-технологического развития Российской Федерации и входящих в нее субъектов. Первоначальную оценку потенциальной опасности негативных

\footnotetext{
${ }^{4}$ В странах, применяющихсанкции по отношениюкРФ, это официальное название списков лиц, которым запрещен въезди проведение финансовых операций через банки стран, объявивших санкции.

${ }_{5}^{5}$ Так, 3 марта 2016 г. президент США Барак Хусейн Обама подписал указ, во второй раз продлевающий «многие меры в отношении российских официальныхлици бизнесменов, входящихв узкий кругпрезидента В. Путина, а также ряда ключевых российскихкомпаний. Меры запрещают им посещать США, иметь там активы и вести бизнес с некоторыми компаниями СоединенныхШтатов. ...Эти меры, называемые "целенаправленными санкциями", призваны создать дискомфорт для российского руководства и ударить по российским государственным компаниям, показать неодобрение Coединенных Штатов и удержать Москву от дальнейшего захвата земель» [2].
} 
воздействий вышеназванных мер, определяющих состояние и динамику хозяйственного развития (факторов экономического развития), можно оценить по показателям оборота внешней торговли, поступлениям в страну иностранных инвестиций, задолженности по кредитам, предоставленным кредитными организациями юридическим лицам. О влиянии антироссийских санкций можно судить и по величине средств, выплачиваемых за год за импорт технологий и услуг технического характера ${ }^{6}$.

Обобщающим показателем экономического развития страны обычно выступают объем и динамика валового внутреннего продукта, а для ее регионов - валового регионального продукта. Информацию о последних Росстат публикует с лагом в один год и уточняет в последующие годы.

К сожалению, статистический справочник «Регионы России. Социально-экономические показатели. 2015: Стат. сб. Росстат. М., 2015. - 1266 с.» не содержит данные об объемах валовых региональных продуктов в 2014 г. Это, конечно, скрывает глубину произошедшего в 2014 г. экономического спада в субъектах Российской Федерации. Однако его можно оценить с помощью другого обобщающего статистического показателя сальдированного финансового результата (прибыль минус убытки) деятельности организаций. Величина этого показателя, как и валового регионального продукта, зависит от многих событий и процессов, включая названные выше.

При прочих равных условиях опасность тем больше, чем выше значимость факторов, способных причинить ущерб социальноэкономическому развитию хозяйствующих субъектов. В качестве показателя такой значимости примем отношение рассматриваемых величин к объему валового регионального продукта. Чем больше значения этих относительных (т.е. отнесенных к величине ВРП) показателей в 2013 г., тем серьезнее в 2014 г. была потенциальная опасность того, что уменьшение оборота внешней торговли, сокращение притока иностранных инвестиций, рост задолженности по кредитам отрицательно скажутся на экономическом развитии страны и ее регионов.

На основе относительных показателей по разработанной автором методике [4] были рассчитаны интегральные индикаторы

\footnotetext{
${ }^{6}$ Оценку введенных против РФ финансово-экономических санкций см., например, в работе [3].
} 
потенциальной опасности нежелательного изменения названных факторов экономического развития для 82 субъектов Российской Федерации. Десять субъектов Российской Федерации, у которых значения интегральных показателей в 2013 г. были самыми плохими, приведены в таблице 1.

\section{Таблица 1. Субъекты РФ с наиболее высокой потенциальной опасностью негативного воздействия нежелательной динамики объемов внешней торговли со странами дальнего зарубежья (T), поступления в РФ прямых иностранных инвестиций (FDI) и задолженности по кредитам (Dbt) в 2013 г., долл./тыс. руб.}

\begin{tabular}{|c|c|c|c|}
\hline \multirow[b]{2}{*}{ Субъект РФ } & \multicolumn{3}{|c|}{ Отношение к ВРП } \\
\hline & $\mathbf{T}$ & FDI & $\begin{array}{c}\text { Dbt, } \\
\text { руб./руб. }\end{array}$ \\
\hline Калужская область & 25,01 & 1,28 & 0,32 \\
\hline Ленинградская область & 26,03 & 0,83 & 0,33 \\
\hline Белгородская область & 5,50 & 2,81 & 0,46 \\
\hline Кемеровская область & 17,64 & 0,27 & 0,47 \\
\hline Курская область & 2,46 & 0,32 & 0,54 \\
\hline Республика Мордовия & 1,22 & 0,03 & 0,57 \\
\hline Тюменская область ${ }^{7}$ & 24,88 & 12,95 & 0,22 \\
\hline Санкт-Петербург & 20,90 & 2,57 & 0,58 \\
\hline Москва & 27,90 & 3,41 & 0,65 \\
\hline Калининградская область & 47,67 & $-0,09$ & 0,54 \\
\hline
\end{tabular}

Примечание к табл. 1, 2, 4: 1) субъекты РФ расположены в порядке ухудшения значения интегрального показателя потенциальной опасности; 2) знак «-» означает снижение.

Источник табл. 1-2, 5-9: рассчитаны по данным стат. сб.: «Регионы России. Социально-экономические показатели» за 2010-2015 гг. [1].

Ранжирование субъектов РФ по значению интегрального индикатора фактических изменений объема товарооборота со странами дальнего зарубежья, величине поступлений прямых иностранных вложений и размера роста задолженности по кредитам, предоставленным физическим и юридическим лицам в рублях и иностранной валюте, определило отличную от представленной в таблице 1 десятку наиболее пострадавших субъектов Федерации (табл. 2). Эти два набора совпали на $50 \%$.

${ }^{7}$ В работе везде Тюменская область дается без Ханты-Мансийского и Ямало-Ненецкого автономных округов. 


\section{Таблица 2. Изменение объемов сальдированного финансового результата деятельности организаций в 2014 г. по сравнению с 2013 г., трлн руб.}

\begin{tabular}{|l|c|l|c|}
\hline $\begin{array}{c}\text { Ранжирование по интегральному } \\
\text { индикатору потенциальной опасности } \\
\text { ухудшения значений трех показателей }\end{array}$ & Трлн руб. & $\begin{array}{c}\text { Ранжирование по интегральному } \\
\text { индикатору фактического измене- } \\
\text { ния значений трех показателей }\end{array}$ & Трлн руб. \\
\hline Калужская область & $-28,6$ & Челябинская область & $+60,1$ \\
\hline Ленинградская область & $-57,5$ & Белгородская область & $+93,2$ \\
\hline Белгородская область & $+93,2$ & Калужская область & $-28,6$ \\
\hline Кемеровская область & $-88,1$ & Ростовская область & $-41,4$ \\
\hline Курская область & $-8,3$ & Ханты-Мансийский АО & $+196,3$ \\
\hline Республика Мордовия & $-2,4$ & Республика Татарстан & $-18,1$ \\
\hline Тюменская область & $-73,1$ & Московская область & $-120,1$ \\
\hline Санкт-Петербург & $-242,3$ & Санкт-Петербург & $-242,3$ \\
\hline Москва & $-1215,4$ & Тюменская область & $-73,1$ \\
\hline Калининградская область & $-19,5$ & Москва & $-1215,4$ \\
\hline
\end{tabular}

Доля субъектов Федерации, наиболее подверженных потенциальной опасности из-за ухудшения трех рассматриваемых показателей, в общем объеме уменьшения в РФ в 2014 г. сальдированного результата составила $57,5 \%$, субъектов РФ с наихудшими интегральными индикаторами фактического изменения этих показателей - 57,7\%. Это указывает на то, что значительны как потенциальная опасность ухудшения экономического положения для субъектов Российской Федерации в 2014 г., так и происшедшее ухудшение. Существовавшие угрозы, по-видимому, реализовались.

\section{Оценка ухудшения ситуации в 2014 г.}

Для более полной оценки последствий воздействия на экономику субъектов Российской Федерации ухудшающейся конъюнктуры мировых товарных рынков, экономического спада внутри страны и антироссийских санкций рассмотрим изменения в 2014 г. по сравнению с 2013 г. пяти названных в начале статьи показателей:

- оборота внешней торговли РФ со странами дальнего зарубежья (в фактически действовавших ценах);

- объема поступлений прямых иностранных инвестиций в РФ (сальдо операций платежного баланса РФ); 
- размера задолженности по кредитам, предоставленным кредитными организациями юридическим лицам в рублях и иностранной валюте;

- величины сальдированного финансового результата деятельности организаций (прибыль минус убытки);

- объема выплаты средств за год за импорт технологий и услуг технического характера.

Для этого сначала проранжируем (отдельно по положительным и отрицательным величинам) все субъекты РФ в порядке убывания доли каждого из рассматриваемых показателей в значениях по стране в целом в 2013 г. и 2014 г. По итогам ранжирования были выбраны субъекты Федерации, суммарная доля которых хотя бы в одном из исследуемых показателей превышала 90\%. Их оказалось 62 (табл. 3), 40 из них расположены к западу от Уральских гор.

\section{Таблица 3. Число субъектов РФ, суммарная доля значений показателей которых превышает $90 \%$ величины показателей для России в целом, ед.}

\begin{tabular}{|l|c|c|c|c|}
\hline \multicolumn{1}{|c|}{ Показатель } & \multicolumn{2}{|c|}{$\begin{array}{c}\text { Значение показа- } \\
\text { теля в 2013 г. }\end{array}$} & \multicolumn{2}{|c|}{$\begin{array}{c}\text { Значение показа- } \\
\text { теля в 2014 г. }\end{array}$} \\
\cline { 2 - 6 } & $\begin{array}{c}\text { положи- } \\
\text { тельно }\end{array}$ & $\begin{array}{c}\text { отрица- } \\
\text { тельно }\end{array}$ & $\begin{array}{c}\text { положи- } \\
\text { тельно }\end{array}$ & $\begin{array}{c}\text { отрица- } \\
\text { тельно }\end{array}$ \\
\hline Поступление прямых иностранных инвестиций & 11 & 18 & 11 & 16 \\
\hline $\begin{array}{l}\text { Сальдированный финансовый результат деятельности } \\
\text { организаций }\end{array}$ & 21 & 17 & 16 & 21 \\
\hline Оборот внешней торговли со странами дальнего зарубежья & 24 & - & 23 & \\
\hline $\begin{array}{l}\text { Выплата средств за год за импорт технологий и услуг } \\
\text { технического характера }\end{array}$ & 19 & - & 2 & - \\
\hline Задолженность по кредитам & 38 & - & 38 & - \\
\hline
\end{tabular}

Источник табл. 3-4: составлены автором.

Приведенные в таблице 3 данные показывают, что в 20132014 гг. свыше 90\% всего товарооборота Российской Федерации, поступлений прямых иностранных инвестиций, импорта технологий и услуг технического характера приходилось менее чем на 30\% всех субъектов Федерации (от 11 до 24 регионов). Естественно ожидать, что ухудшение геополитической обстановки и финансово-экономической ситуации в России скажется прежде всего на них. 
Для этих 62 субъектов Российской Федерации был рассчитан интегральный индикатор изменения значений пяти рассматриваемых показателей в 2014 г. Его лучшее значение соответствует наименьшему совокупному ухудшению рассматриваемых показателей, а худшее - наибольшему. В таблице 4 приведены десять субъектов Федерации, у которых взятое в совокупности изменение исследуемых показателей в 2014 г. было меньше, чем у других, и десять субъектов РФ, у которых такое изменение было самым большим.

\section{Таблица 4. Субъекты РФ с наименьшим и наибольшим изменением рассматриваемых групп показателей ${ }^{8}$}

\begin{tabular}{|l|l|}
\hline $\begin{array}{l}10 \text { первых - с лучшими значениями } \\
\text { интегрального индикатора }\end{array}$ & $\begin{array}{l}10 \text { последних - с худшими значениями } \\
\text { интегрального индикатора }\end{array}$ \\
\hline $\begin{array}{l}\text { Астраханская область } \\
\text { Республика Башкортостан } \\
\text { Белгородская область } \\
\text { Краснодарский край }\end{array}$ & $\begin{array}{l}\text { Архангельская область } \\
\text { Ямало-Ненецкий автономный округ } \\
\text { Мурманская область }\end{array}$ \\
Чеченская Республика & Московская область \\
Сахалинская область & Волгоградская область \\
Чувашская Республика & Санкт-Петербург \\
Саратовская область & Калужская область \\
Ставропольский край & Республика Татарстан \\
\hline
\end{tabular}

Наиболее сильное влияние на величину рассчитанного интегрального индикатора многих субъектов Федерации оказали увеличение задолженности по кредитам, предоставленным кредитными организациями юридическим лицам в рублях и иностранной валюте, сокращение объема поступлений в страну прямых иностранных инвестиций и уменьшение величины сальдированного финансового результата деятельности организаций. На долю каждого из значений этих показателей в общей величине рассчитанных интегральных индикаторов приходилось от 18 до 25\% ${ }^{9}$. Для Калининградской области и Москвы наиболее значимым было падение объема внешнеторгового оборота со странами дальнего зарубежья (25\%). Вторым по значимости для Москвы было уменьшение объема импорта технологий

${ }^{8}$ Здесь и далее субъекты РФ располагаются в порядке ухудшения значения интегрального индикатора рассматриваемого набора показателей.

${ }^{9}$ Способ расчета описан в [4]. 
и услуг технического характера (21\%). В интегральном индикаторе Астраханской области доля уменьшения объема импорта технологий и услуг технического характера составила $23 \%$, Тюменской области - 19,7\%, Санкт-Петербурга - 13,7\%, Московской области - $12 \%$, Белгородской - 11,8\%. Средняя арифметическая величина «вклада» уменьшения размера импорта технологий и услуг технического характера в интегральный индикатор рассматриваемой группы показателей ${ }^{10}$ равнялась 7,0\% и менялась в интервале от 2,1\% (Калининградская область) до 23,2\% (Астраханская область).

Думается, что на сокращение объемов импорта технологий и услуг технического характера наиболее сильно повлияли финансово-экономические санкции против Российской Федерации, введенные руководством США, ЕС и ряда других государств. Объемы задолженности по кредитам, предоставленным юридическим лицам в рублях и иностранной валюте, я ставлю на второе место по силе воздействия антироссийских санкций на рассматриваемые здесь пять показателей (их средняя по субъектам РФ относительная доля в величине рассчитанного интегрального индикатора равна $24,7 \%$ ). Третье место, думается, следует отдать объему оборота внешней торговли со странами дальнего зарубежья (средняя относительная доля в интегральном индикаторе составила 20,6\%).

Полагаю, что на снижение поступлений в Россию прямых иностранных инвестиций (средняя относительная доля в величине полученного интегрального индикатора равна 24,5\%) санкции повлияли слабее, чем состояние конъюнктуры мирового рынка, финансово-экономическое положение основных экспортеров капитала, экономическая ситуация и инвестиционный климат в странах-реципиентах прямых иностранных инвестиций, включая Российскую Федерацию.

У десяти регионов с лучшими значениями интегрального индикатора (см. табл. 4) в 2014 г. рост задолженности по кредитам, предоставленным кредитными организациями юридическим лицам в рублях и иностранной валюте, сокращение объемов внешнеторгового оборота со странами дальнего зарубежья, уменьшение поступления прямых иностранных инвестиций

10 Термины «показатель» и «индикатор»в работе используются как синонимы. 
и сальдированного финансового результата деятельности организаций оказались меньше, чем у остальных субъектов РФ. При этом увеличилась сумма средств, выплаченных за импорт технологий и услуг технического характера ${ }^{11}$ (табл. 5).

\section{Таблица 5. Изменение рассматриваемых показателей трех групп субъектов РФ в 2014 г. по сравнению с 2013 г.}

\begin{tabular}{|c|c|c|c|}
\hline \multirow{2}{*}{ Показатель } & \multicolumn{3}{|c|}{$\begin{array}{l}\text { Субъекты РФ, объединенные в группы } \\
\text { по значению интегрального индикатора }\end{array}$} \\
\hline & 10 первых & 10 последних & остальные 42 \\
\hline $\begin{array}{l}\text { Задолженности по кредитам, предоставленным кре- } \\
\text { дитными организациями юридическим лицам в рублях } \\
\text { и иностранной валюте, млрд руб. }\end{array}$ & $+213,7$ & $+1500,3$ & $+943,1$ \\
\hline $\begin{array}{l}\text { Поступление прямых иностранных инвестиций в РФ } \\
\text { (сальдо операций платежногобалансаРФ), млндолл. США }\end{array}$ & $-473,0$ & $-42475,0$ & $-3414,0$ \\
\hline $\begin{array}{l}\text { Оборот внешней торговли со странами дальнего зарубе- } \\
\text { жья, в фактически действовавших ценах, млн долл. США }\end{array}$ & $-1664,7$ & $-34258,7$ & $-8963,8$ \\
\hline $\begin{array}{l}\text { Сальдированный финансовый результат деятельности } \\
\text { организаций (прибыль-убытки), трлн руб. }\end{array}$ & $-160,6$ & - 2023,4 & $-323,0$ \\
\hline $\begin{array}{l}\text { Выплата средств за год за импорт технологий и услуг } \\
\text { технического характера, млн долл. США }\end{array}$ & $+559,2$ & $-505,8$ & $-62,1$ \\
\hline
\end{tabular}

Примечание: знак «+» означает увеличение, знак «-»- снижение.

Анализ отраслевой структуры валовой добавленной стоимости рассматриваемых 62 субъектов Российской Федерации не выявил ее значимой связи с изменением исследуемых показателей в 2014 г., хотя в структуре валовой добавленной стоимости 2013 г. у группы субъектов Федерации с наихудшей динамикой изменения совокупности исследуемых показателей доли обрабатывающих производств, оптовой и розничной торговли, операций с недвижимым имуществом были несколько выше, чем у других субъектов РФ (табл. 6). Эти отрасли наиболее подвержены

11 В соответствии с федеральным законом от 29.11.2007 г. № 282-Ф3 "Об официальном статистическом учете и системе государственной статистики в Российской Федерации» (п.5 ст. 4, ч.1 ст. 9) суммы средств, выплаченных Чеченской Республикой и Сахалинской областью за импорт технологий и услуг технического характера, не публикуются в целях обеспечения конфиденциальности первичных статистических данных, полученных от организаций.

З ЭКО. - 2016. - №5 
воздействию мировой конъюнктуры, антироссийских санкций и падения отечественной экономики.

\section{Таблица 6. Средние арифметические долей отдельных отраслей в структуре валовой добавленной стоимости групп субъектов РФ в 2013 г., \%}

\begin{tabular}{|l|c|c|c|}
\hline \multirow{2}{*}{ Отрасль } & \multicolumn{3}{|c|}{ Субъекты РФ, объединенные в группы } \\
\cline { 2 - 4 } & по значению интегрального индикатора \\
\cline { 2 - 4 } & $\mathbf{1 0}$ первых & $\mathbf{1 0}$ последних & остальные 42 \\
\hline Сельское хозяйство, охота и лесное хозяйство & 8,2 & 3,6 & 6,3 \\
\hline Добыча полезных ископаемых & 9,4 & 12,5 & 10,2 \\
\hline Обрабатывающие производства & 14,1 & 20,4 & 17,8 \\
\hline Строительство & 9,6 & 7,9 & 6,8 \\
\hline $\begin{array}{l}\text { Оптовая и розничная торговля; ремонт автотранс- } \\
\text { портных средств, мотоциклов, бытовых изделий } \\
\text { и предметов личного пользования }\end{array}$ & 13,7 & 15,8 & 14,0 \\
\hline Транспорт и связь & 8,3 & 10,4 & 10,2 \\
\hline $\begin{array}{l}\text { Операции с недвижимым имуществом, аренды } \\
\text { и предоставление услуг }\end{array}$ & 6,8 & 11,6 & 8,5 \\
\hline
\end{tabular}

Основную долю в структуре объема отгруженной продукции (работ, услуг) по виду экономической деятельности «Обрабатывающие производства» в 2014 г. у шести субъектов из десятки лучших по динамике изменения совокупности исследуемых показателей в 2014 г. занимало производство пищевых продуктов, включая напитки и табак, у двух - производство кокса, нефтепродуктов, химическое, а также резиновых и пластмассовых изделий, у одного субъекта Федерации - выпуск машин, транспортных средств и оборудования и еще у одного - производство электро-, электронного и оптического оборудования. Такая структура отгруженной продукции дает основание предполагать, что обрабатывающие производства данной группы субъектов Федерации работают преимущественно на внутренний рынок.

Десять субъектов Российской Федерации с наихудшей динамикой изменения совокупности исследуемых показателей в 2014 г. имели другую структуру объема отгруженной продукции (работ, услуг) по виду экономической деятельности «Обрабатывающие производства». У семи из них в этой структуре преобладало производство кокса, нефтепродуктов, химическое производство, а также резиновых и пластмассовых изделий, у двух - машин, 
транспортных средств и оборудования и у одного субъекта Федерации - производство пищевых продуктов, включая напитки и табак. При такой структуре отгруженной продукции можно предполагать, что обрабатывающие производства этой группы субъектов Федерации ориентированы преимущественно на внешний рынок.

Представляется, что на анализируемые показатели влияла не столько отраслевая структура валовой добавленной стоимости и видов экономической деятельности, сколько зависимость хозяйствующих субъектов от иностранного капитала, внешних источников финансирования и внешнеторгового оборота. Статистическая проверка показала наличие связи исследуемых объемов внешнеторгового оборота, прямых иностранных инвестиций и задолженности по кредитам с величиной сальдированного финансового результата для 82 субъектов РФ в 2013 г. и 2014 г.: коэффициенты линейной корреляции значимы с двусторонним критерием ошибки $1 \%(\alpha=0,01)$. Исследование статистики 82 субъектов Российской Федерации ${ }^{12}$ также дает основание полагать следующее.

1. Статистическая связь объемов внешнеторгового оборота с величиной сальдированного финансового результата в 2013 г. и в 2014 г. сильнее, чем связь объемов прямых иностранных инвестиций и задолженности по кредитам с величиной сальдированного финансового результата. Что говорит о более существенной в эти годы связи финансовых результатов субъектов РФ с состоянием внешней торговли, чем с размером поступающих в регионы прямых иностранных инвестиций и задолженностью по кредитам.

2. Статистическая связь рассматриваемых показателей в 2014 г. слабее, чем в 2013 г., что указывает на ослабление зависимости финансовых результатов субъектов Федерации от рассматриваемых внешних факторов.

Субъекты Федерации, экономика которых больше ориентирована на внешние рынки сбыта и импорта продукции и услуг, больше подвержены влиянию внешней конъюнктуры и введенных рядом стран против России финансово-экономических санкций (табл. 7). Кроме того, осуществление внешнеторговой деятельности требует заемных средств.

12 Проверялась гипотеза о равенстве коэффициентов линейной корреляции. 
Таблица 7. Отношение значений оборота внешней торговли со странами дальнего зарубежья (T), полученных прямых иностранных инвестиций (FDI) и задолженности по кредитам, предоставленным кредитными организациями юридическим лицам в рублях и иностранной валюте (Dbt) в 2014 г., к объему ВРП 2013 г., долл./тыс. руб.

\begin{tabular}{|l|c|c|c|}
\hline \multicolumn{1}{|c|}{ Группа субъектов РФ } & T & FDI & $\begin{array}{c}\text { Dbt, } \\
\text { руб./руб. }\end{array}$ \\
\hline 10 субъектов РФ с лучшими значениями интегрального индикатора & 9,1 & 0,6 & 0,3 \\
\hline 10 субъектов РФ с худшими значениями интегрального индикатора & 21,6 & 2,7 & 0,5 \\
\hline Остальные субъекты РФ & 7,9 & 0,2 & 0,3 \\
\hline
\end{tabular}

Для более полного учета влияния экономической конъюнктуры и антироссийских санкций на финансово-экономическую ситуацию в субъектах Российской Федерации лучше было бы работать с данными о размерах портфельных и прочих поступающих в Россию иностранных инвестиций. Портфельные инвестиции больше, чем прямые, зависят от экономической и политической ситуаций в стране и в мире в целом, а основной объем приходящих в Российскую Федерацию прочих иностранных инвестиций составляют торговые кредиты. При этом объем прочих инвестиций заметно больше, чем прямых (рис. 4). К сожалению, за 2014 г. Росстат опубликовал информацию только о размере поступивших в Российскую Федерацию прямых иностранных инвестиций. Они и использованы в настоящем исследовании.

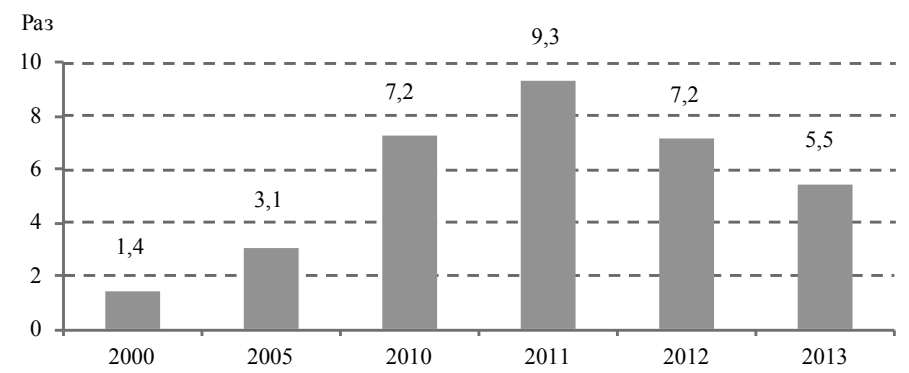

Рис. 4. Отношение объема прочих инвестиций к объему прямых в 2000-2013 гг., раз

На 10 субъектов РФ с лучшими значениями интегрального индикатора приходилась треть прироста стоимости товарооборота Российской Федерации со странами дальнего зарубежья в 2014 г. (на 10 с худшими значениями интегрального индикатора - 
четверть), более трети снижения задолженности по кредитам и более $91 \%$ от общего увеличения импорта технологий и услуг технического характера (табл. 8). Их доля в общем объеме ухудшения значений рассматриваемых показателей не превышала 9\%, в то время как доля 10 субъектов Федерации с худшими значениями интегрального индикатора менялась в пределах от 55 до $81 \%$ (табл. 9).

\section{Таблица 8. Доля изменения величины показателя в группах субъектов РФ в общем объеме улучшения значения показателя в РФ в 2014 г., \%}

\begin{tabular}{|l|c|c|c|}
\hline \multirow{2}{*}{\multicolumn{1}{|c|}{ Показатель }} & \multicolumn{2}{c|}{\begin{tabular}{c}
\multicolumn{2}{c|}{ Субъекты РФ, объединенные в группы } \\
по значению интегрального индикатора
\end{tabular}} \\
\cline { 2 - 4 } & $\mathbf{1 0}$ первых & $\mathbf{1 0}$ последних & остальные 62 \\
\hline Оборот внешней торговли со странами дальнего зарубежья & 33,1 & 25,0 & 41,9 \\
\hline Поступление прямых иностранных инвестиций в РФ & 20,6 & 2,9 & 76,5 \\
\hline Задолженность по кредитам & 36,5 & 0,0 & 63,5 \\
\hline Выплата средств за импорт технологий и услуг технического характера & 91,3 & 0,3 & 8,4 \\
\hline Сальдированный финансовый результат деятельности организаций & 17,8 & 2,4 & 79,8 \\
\hline
\end{tabular}

\section{Таблица 9. Доля изменения величины показателя В группах субъектов РФ в общем объеме ухудшения значения показателя в РФ в 2014 г., \%}

\begin{tabular}{|l|c|c|c|}
\hline \multirow{2}{*}{ Показатель } & \multicolumn{3}{|c|}{$\begin{array}{c}\text { Субъекты РФ, объединенные в группы } \\
\text { по значению интегрального индикатора }\end{array}$} \\
\cline { 2 - 5 } & $\mathbf{1 0}$ первых & $\mathbf{1 0}$ последних & остальные $\mathbf{6 2}$ \\
\hline Оборот внешней торговли со странами дальнего зарубежья & 3,1 & 72,7 & 24,2 \\
\hline Поступление прямых иностранных инвестиций в РФ & 3,7 & 80,4 & 15,9 \\
\hline Задолженность по кредитам & 8,6 & 55,4 & 36,0 \\
\hline $\begin{array}{l}\text { Выплата средств за импорт технологий и услуг } \\
\text { технического характера }\end{array}$ & 0,0 & 81,0 & 19,0 \\
\hline $\begin{array}{l}\text { Сальдированный финансовый результат } \\
\text { деятельности организаций }\end{array}$ & 8,5 & 68,3 & 23,2 \\
\hline
\end{tabular}

\section{$\star \star \star$}

В кратком виде результаты представленного в настоящей статье исследования можно сформулировать следующим образом.

Выполненные расчеты показали, что снижение объемов внешней торговли Российской Федерации, уменьшение поступления в страну иностранных инвестиций, рост задолженности хозяйствующих субъектов внутри страны, частично 
обусловленные действием антироссийских санкций, представляют заметную угрозу экономике России и ее регионов.

В 2014 г. такая угроза реализовалась. Под влиянием названных и ряда других факторов экономическое развитие Российской Федерации замедлилось, социально-экономическое положение части регионов ухудшилось.

Поскольку достижение свыше 90\% объема рассматриваемых экономических показателей обеспечивает узкий круг субъектов РФ (11-24 региона), именно их экономика в 2014 г. пострадала больше, чем остальных.

Сила влияния экономического спада в России, ухудшения конъюнктуры на мировых товарных рынках и введенных против Российской Федерации финансово-экономических санкций на изменение совокупности анализируемых показателей субъектов Федерации прямо пропорциональна зависимости хозяйствующих субъектов от иностранного капитала, внешних источников финансирования и внешнеторгового оборота.

Ориентация экономики субъектов Федерации на внешние рынки сбыта и импорта продукции и услуг делает этих субъектов более уязвимыми к неблагоприятному воздействию внешней конъюнктуры и введенных против России финансовоэкономических санкций.

Связь показываемых субъектами Российской Федерации финансовых результатов с внешнеторговой деятельностью регионов в 2013-2014 гг. была сильнее, чем с объемами получаемых прямых иностранных инвестиций и с величиной задолженности по кредитам, предоставленным кредитными организациями юридическим лицам. Связь финансовых результатов субъектов Федерации с этими факторами роста в 2014 г. слабее, чем в 2013 г., что указывает на усиление влияния других факторов.

\section{Литература}

1. Регионы России. Социально-экономические показатели. URL: http:// www.gks.ru/wps/wcm/connect/rosstat_main/rosstat/ru/statistics/publications/ catalog/doc_1138623506156 (дата обращения: 25.01.2016).

2. Obama Prolongs Sanctions on Russia Over Ukraine Crisis. URL: http:// abcnews.go.com/International/obama-extends-sanctions-russia-ukraine-crisis/ story? id $=37362950$

3. Казанцев С. В. Антироссийские санкции - вчера и сегодня // ЭКО. 2015. - № 3. - C.63-78.

4. Казанцев С. В. Защищенность экономики регионов России. Монография. - Новосибирск: ИЭОПП СО РАН. - 2014. - 180 с. 